\title{
Oral Drops, Powder for Suspension Dosage Form
}

National Cancer Institute

\section{Source}

National Cancer Institute. Oral Drops, Powder for Suspension Dosage Form. NCI

Thesaurus. Code C149710.

Solid preparation consisting of one or more powders intended to be dispersed in the specified liquid to obtain an oral drops suspension. 